\title{
Fine mapping and RNA-Seq unravels candidate genes for a major QTL controlling multiple fiber quality traits at the $T_{1}$ region in upland cotton
}

Dexin Liu ${ }^{\dagger}$, Jian Zhang ${ }^{\dagger}$, Xueying Liu, Wenwen Wang, Dajun Liu, Zhonghua Teng, Xiaomei Fang, Zhaoyun Tan, Shiyi Tang, Jinghong Yang, Jianwei Zhong and Zhengsheng Zhang ${ }^{*}$

\begin{abstract}
Background: Improving fiber quality is a major challenge in cotton breeding, since the molecular basis of fiber quality traits is poorly understood. Fine mapping and candidate gene prediction of quantitative trait loci (QTL) controlling cotton fiber quality traits can help to elucidate the molecular basis of fiber quality. In our previous studies, one major QTL controlling multiple fiber quality traits was identified near the $T_{1}$ locus on chromosome 6 in Upland cotton.

Results: To finely map this major QTL, the $F_{2}$ population with 6975 individuals was established from a cross between Yumian 1 and a recombinant inbred line (RIL118) selected from a recombinant inbred line population (T586 × Yumian 1). The QTL was mapped to a 0.28-cM interval between markers HAU2119 and SWU2302. The QTL explained $54.7 \%(\mathrm{LOD}=222.3), 40.5 \%(\mathrm{LOD}=145.0), 50.0 \%(\mathrm{LOD}=194.3)$ and $30.1 \%(\mathrm{LOD}=100.4)$ of phenotypic variation with additive effects of $2.78,-0.43,2.92$ and 1.90 units for fiber length, micronaire, strength and uniformity, respectively. The QTL region corresponded to a 2.7-Mb interval on chromosome 10 in the G. raimondii genome sequence and a 5.3-Mb interval on chromosome A06 in G. hirsutum. The fiber of Yumian 1 was much longer than that of RIL 118 from 3 DPA to 7 DPA. RNA-Seq of ovules at 0 DPA and fibers at 5 DPA from Yumian 1 and RIL118 showed four genes in the QTL region of the G. raimondii genome to be extremely differentially expressed. RT-PCR analysis showed three genes in the QTL region of the $G$. hirsutum genome to behave similarly.

Conclusions: This study mapped a major QTL influencing four fiber quality traits to a 0.28-cM interval and identified three candidate genes by RNA-Seq and RT-PCR analysis. Integration of fine mapping and RNA-Seq is a powerful strategy to uncover candidates for QTL in large genomes.
\end{abstract}

Keywords: Fiber quality, Trichome, Fine mapping, Quantitative trait loci (QTL), RNA-Seq, Gossypium hirsutum L.

\footnotetext{
* Correspondence: zhangzs@swu.edu.cn

${ }^{\dagger}$ Equal contributors

Engineering Research Center of South Upland Agriculture, Ministry of

Education, Southwest University, 400716 Chongqing, People's Republic of

China
} 


\section{Background}

Cotton is the world's leading natural fiber and second most valuable oil crop [1]. The cotton fiber, a seed borne epidermal trichome, is a model system for the study of cell elongation and cell wall and cellulose biosynthesis [2]. On the day of anthesis, cells of the ovular epidermis have already been determined to become trichomes, and subsequently undergo elongation, secondary cell wall synthesis and maturation, which are overlapping steps in a complex developmental process [2]. Although many studies have focused on identification of key genes controlling fiber development at different developmental phases [3-5], the molecular mechanisms of fiber development are still not fully understood.

DNA markers provide a powerful tool to study molecular mechanisms underlying complex traits, and facilitate an effective strategy for crop improvement marker-assisted selection (MAS). Over the last decade, at least 1,075 quantitative trait loci (QTL) from 58 studies of intraspecific G. hirsutum and 1,059 QTL from 30 studies of G. hirsutum $\times$ G. barbadense populations have been published, for yield, fiber and seed quality, and biotic and abiotic stress tolerance [6]. However, these QTL are localized to large genomic regions that provide only coarse resolution for MAS in cotton breeding, and may include hundreds or even thousands of genes. To precisely select for target genes with a minimum of 'linkage drag' from nearby undesirable alleles requires fine-mapping of QTL, and preferably identification of candidate genes.

Due to the complexity of the tetraploid cotton genome, few studies of QTL fine mapping have been reported [7-9]. Cotton genome sequencing [10-14] has provided a rich source of DNA markers for fine mapping, and made it routine to predict QTL candidate genes.

Besides DNA marker technology, technological developments in high-throughput sequencing also offer new opportunities to elucidate mechanisms underlying complex traits. Considerable research has been conducted on the global molecular and biochemical processes underlying fiber development through expressed sequence tag (EST) analysis $[3,15]$, macro- or microarray gene expression profiling $[16,17]$ and transcriptome analysis [18, 19]. These studies have highlighted the stage-specific transcription of genes involved in fiber initiation, elongation and secondary cell wall formation. For example, GhMYB25 [20], GhMYB25-like [21], GhSusA1 [22], GbPDF1 [23], GhHD-1 [5], GhFLA1 [24] and GhVIN1 [25] have been demonstrated to have definite roles in cotton fiber initiation, and Sus [26], ACTIN1 [27], GhSusA1 [22], GhPIP2 [28], WLIM1a [29], GhFLA1 [24], GhHOX3 [30], GhCaM7 [31] and GhPAG1 [32] play roles in controlling cotton fiber elongation.

Rich information about cotton QTL and expanded scope for fine mapping, together with a growing body of developmental and transcriptomic information, sets the stage for unraveling relationships between specific genes and empirically-measured fiber quality traits such as fiber length, strength, fineness, and elongation. Many studies showed that the integration of quantitative genetics and transcriptomic data was very helpful to propose short lists of candidate genes in plants, for example in Populus spp, Glycine max L. and Triticum aestivum L. [33-35].

In our previous studies, one QTL affecting cotton lint percentage, fiber length, uniformity, strength and micronaire was identified near the $T_{1}$ locus on chromosome 6 affecting leaf pubescence [36]. The QTL was initially identified using an $F_{2}$ population (T586 $\times$ Yumian 1) in upland cotton and confirmed in a recombinant inbred line population (T586 $\times$ Yumian 1) in multiple environments $[36,37]$. The $\mathrm{T}_{1}$ allele was associated with short and coarse fibers, increased micronaire and high trichome density on the vegetative parts of plants [38-41]. A recent study linked the absence of stem trichomes of $G$. barbadense to a copia-like retrotransposon insertion in a homeodomain leucine zipper gene $(H D-1)$, which was found to co-segregate with $\mathrm{T}_{1}$ on chromosome 6 [42]. Silencing of GhHD-1 reduced trichome formation and delayed the timing of fiber initiation. Over expression of GhHD-1 increased the number of fibers initiating on the seed and thereby increased fuzz percentage, but did not affect fiber quality traits [5]. These results suggested that the gene/s for the QTL near the $\mathrm{T}_{1}$ locus and the gene for $\mathrm{T}_{1}$ itself might not be the same.

In the present study, a large segregating population was established from a cross between Yumian 1 and a recombinant inbred line (RIL118) with trichomes and short coarse fiber selected from a recombinant inbred line population (T586 × Yumian 1). SSR markers were designed from the G. raimondii genome [10] for fine mapping the QTL controlling multiple fiber quality traits in the $T_{1}$ locus region. Digital gene expression profiling was used to identify candidate genes for the QTL controlling fiber quality traits.

\section{Methods \\ Mapping population development and fiber quality measurement}

Based on its genotype and the location of the QTL mapped in the recombinant inbred line population (T586 $\times$ Yumian 1) $[37,43]$, one recombinant line, RIL118, with trichomes and short and coarse fiber, was selected to cross with Yumian 1 in the summer of 2010 at the Teaching and Experiment Farm of Southwest University (SWU), Beibei, Chong qing, China. Chromosome 6 of RIL118 was homozygous for T586 alleles, and the other chromosomes with loci affecting fiber quality (like $\mathrm{N}_{1}, \mathrm{Lc}_{1}$ and $\mathrm{Lg}$ ) are homozygous for Yumian 1 alleles. $F_{1}$ plants were self-pollinated in the winter of 2010 in Sanya, Hainan, China. A total of 


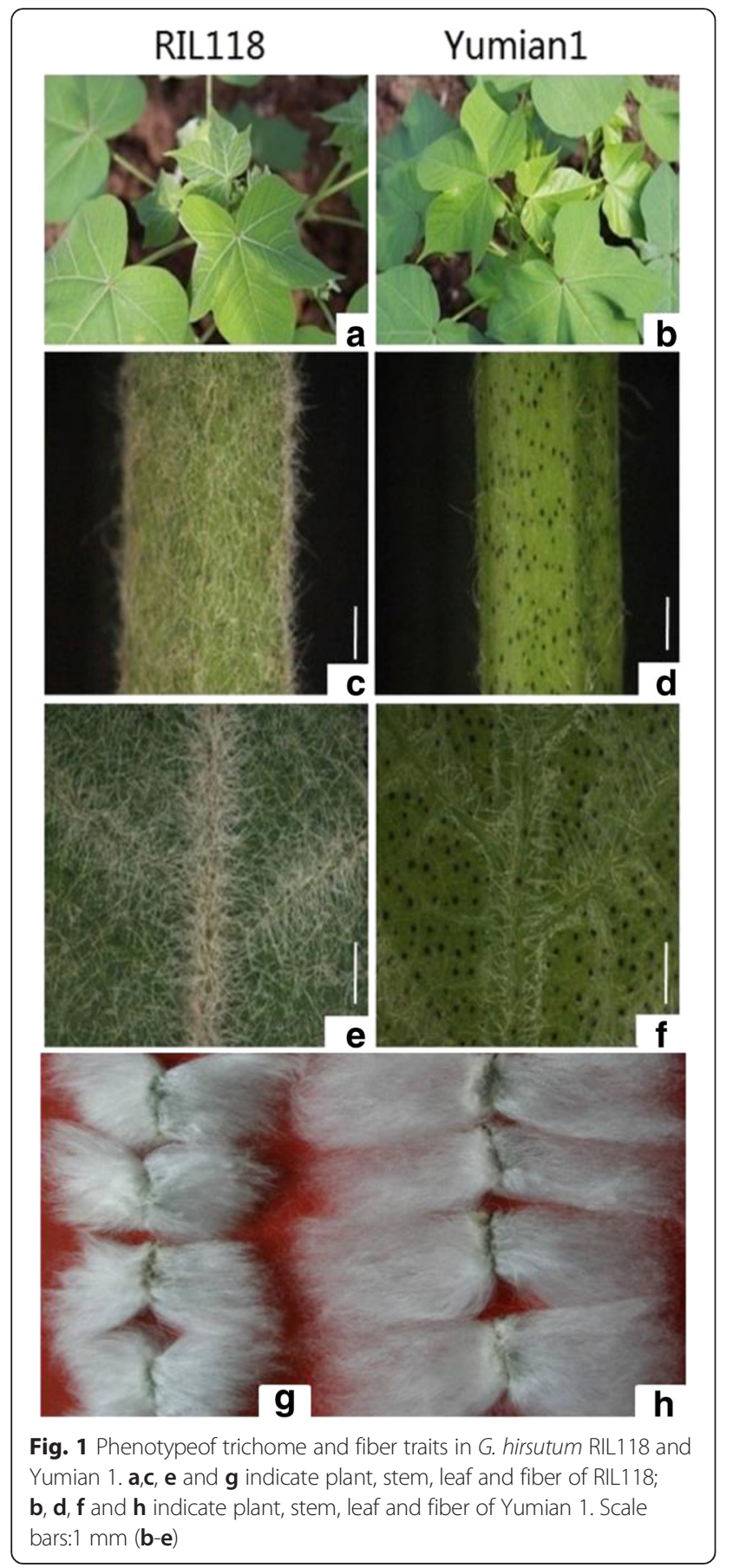

$6975 \mathrm{~F}_{2}$ individuals, including 1434 plants in 2011 and 5541 plants in 2012, were planted at SWU. For the 1434 individuals planted in 2011, all naturally-opened bolls were hand-harvested to gin fiber for fiber quality measurement, including fiber length ( $\mathrm{FL}, \mathrm{mm})$, fiber micronaire reading (FM), fiber strength (FS, $\mathrm{cN} /$ tex), fiber elongation (FE), and uniformity ratio (FU). For the 5541 individuals planted in 2012, only the recombinants were sampled for fiber quality measurement. Fiber samples were measured using HVI
(High Volume Instrument) at the Supervision Inspection and Testing Cotton Quality Center, Anyang, China. The correlation coefficient among fiber quality traits was determined using Statistical Analysis Software (SAS, Cary, NC).

\section{Trichome phenotypes}

Trichome phenotypes were determined qualitatively by viewing young leaves and stems. The trichome phenotypes for RIL118 and Yumian 1 are shown on Fig. 1. Plants from segregating populations grown in the field were classified into three categories i.e., pilose (TT), semi-hairy $(\mathrm{Tt})$ or glabrous (tt), on the basis of mean trichome density, compared with homozygotes for the parental types.

\section{Fiber development observation}

Yumian 1 and RIL118 were grown in 2014 at SWU. Flowers were tied up the day before anthesis to ensure self-pollination. Young bolls were harvested at $0,1,3,5$, and 7 DPA. For scanning electron microscopy, samples (0 and 1 DPA) were prepared as described [44]. The developing cotton ovules were examined and photographed with a Hitachi S-3000 N scanning electron microscope. To monitor the process of fiber elongation for the two parents, an anatomy microscope (Leica, Germany) was used to observe fiber length at 3,5 and $7 \mathrm{DPA}$ in $95^{\circ} \mathrm{C}$ water for $5 \mathrm{~min}$.

\section{Genetic map construction}

Cotton genomic DNA was extracted from young leaves using a modified CTAB method [45].

To enrich markers within the QTL region, three hundred SSR markers were developed from a G. raimondii genome sequence [10]. Primers were synthesized by Shanghai Invitrogen, mapped on chromosome 6 [43], and those with clear polymorphism between Yumian 1 and RIL118 were used to genotype the mapping population. JoinMap4.0 was used to construct the genetic map of the $\mathrm{T}_{1}$ region. The interval mapping method of MapQTL6.0 was used to identify QTL for the five fiber quality traits. A threshold of $\log$ of odds ratio (LOD) $\geq 3.0$ was used to declare QTL. MapChart 2.2 was used to create the linkage group and QTL. QTL were named starting with 'q', followed by a trait abbreviation (e.g., FL for fiber length).

\section{Total RNA isolation}

Total RNA was extracted from ovules at 0 DPA and fibers at 5 DPA. RNA degradation and contamination was monitored on $1 \%$ agarose gels. RNA purity was checked with the Nano Photometer spectrophotometer (IMPLEN, Westlake Village, CA, USA). RNA concentration was measured with the Qubit RNA Assay Kit in a Qubit 2.0 Fluorometer (Life Technologies, Carlsbad, CA, USA). RNA integrity was assessed with the RNA Nano 6000 
Assay Kit of the Bioanalyzer 2100 system (Agilent Technologies, Santa Clara, CA, USA).

\section{Library construction and sequencing}

At least $3 \mu \mathrm{g}$ of total RNA per sample was used for RNA sample preparation. Sequencing libraries were generated using Illumina TruSeq ${ }^{\mathrm{Tm}}$ RNA Sample Preparation Kits (Illumina, San Diego, CA, USA) in accordance with the manufacturer's recommendations. Transcriptome sequencing was carried out on an Illumina HiSeq 2000 platform that produced $100 \mathrm{bp}$ paired-end (PE) raw reads (Novogene Bioinformatics Technology Co.Ltd).

The raw sequence data (from Illumina HiSeqTM2000/ MiSeq) which consisted of raw pictures were first transformed to Sequenced Reads which contained read sequences and corresponding base quality (in FASTQ format) through Base Calling. Raw data (raw reads) was filtered as follows:(1) remove reads with adapter, (2) remove reads containing $\mathrm{N}>10 \%$, (3) remove reads with $\mathrm{sQ} \leq 5$ base percentage $>50 \%$. Q20, Q30 and GC content were calculated. All downstream analyses were based on clean data with high quality.

\section{Mapping clean reads to the reference genome}

The clean sequence tags were mapped to the G. raimondii reference genome [10]. Gene model annotation files came from Phytozome (https://phytozome.jgi.doe.gov/pz/portal.html). An index of the reference genome was built using Bowtie v2.0.6 and PE clean reads were aligned to the reference genome using TopHat v2.0.9.

\section{Quantification and pathway in differential expression analysis of transcripts}

Gene expression levels were measured by transcript abundance. In our RNA-seq analysis, the gene expression level was estimated by counting the reads that mapped to genes or exons. To make gene expression data comparable across different genes and experiments, the parameter FPKM (Fragments Per Kilo base of exon per Million fragments mapped) was used. HTSeq software was used to analyze gene expression levels, using the 'union' model. The result files present the number of genes with different expression levels and the expression levels of single genes.

Because there were no biological replicates, for each sequenced library the read counts were adjusted by the Edger package through one scaling normalized factor. Differential expression analysis of two conditions was performed using the DEGSeq $\mathrm{R}$ packagev 1.12.0. DEGSeq provides statistical routines to determine differential expression in digital gene expression data using a model based on the negative binomial distribution. P-values were adjusted using the Benjamini and Hochberg method. The q-values of 0.05 and $\log 2$ (Fold_change) with no limitations were served as the threshold of significance for differential expression.

Kyoto Encyclopedia of Genes and Genomes (KEGG) is a database resource used to facilitate understanding of the high-level functions and uses of the biological system (http://www.genome.jp/kegg/). Here, KOBAS software was used to test the statistical enrichment of differential expression genes in KEGG pathways.

\section{Validation of candidate genes by real-time quantitative RT-PCR}

Total RNA was extracted from ovules at 0 DPA and fibers at 5, 10,15,20 and 25 DPA of Yumian 1 and RIL118. RNA degradation and contamination was monitored on $1 \%$ agarose gels. First strand cDNA was synthesized from total RNA by priming with oligodT primer using Thermoscript Reverse Transcriptase (Invitrogen, Carlsbad, CA) at $50{ }^{\circ} \mathrm{C}$. RT-PCR was carried out inareaction volume of $20 \mathrm{ml}$ containing $10 \mathrm{ml}$ iTaq $^{\mathrm{TM}} \mathrm{SYBR}^{\circ}$ Green Super mix with ROX (Bio-Rad Laboratories), $1 \mathrm{mM}$ forward and reverse primers, and $0.1 \mathrm{mM} \mathrm{cDNA}$ template in a quantitative real-time PCR kit (Bio-Rad). PCR reactions were performed according to the manufacturer's instructions. Cotton HISTONE3 (AF024716) was used as a loading control to normalize samples. Additional file 1 lists the primer sequences of the four candidate genes based on the Gossypium hirsutum L. reference genome [14].

\section{Results}

\section{Phenotypic analysis of fiber quality traits}

Phenotypic variation for five fiber quality traits was summarized in Additional files 2 and 3. The two parents differed remarkably in these traits, and their $F_{2}$ population of 1434 individuals displayed continuous variation. The average values of fiber quality traits for groups of progeny with different trichome phenotypes are shown in Additional file 4. The fiber quality traits of the $T_{1} T_{1}$ genotype were almost exactly the same as RIL118, and those of the $t_{1} t_{1}$ genotype were similar to Yumian 1 . Additional file 5 showed correlation coefficients for the five fiber traits among $1434 \mathrm{~F}_{2}$ plants. All traits had significant correlation with each other. FM had significant negative correlation with FU, FL and FS, whereas significant positive correlations existed among the other traits.

\section{QTL mapping}

Based on the genetic map and the QTL region for fiber quality traits [37, 43], thirteen newly developed SSR markers from G. raimondii reference genome [10] showed polymorphism between Yumian 1 and RIL118 (Additional file 6). The newly identified SSR markers and SSR markers previously mapped on chromosome 6 were used to genotype $360 \quad F_{2}$ individuals randomly selected from the $2011 \mathrm{~F}_{2}$ population, with a total of 116 loci (115 SSR and 


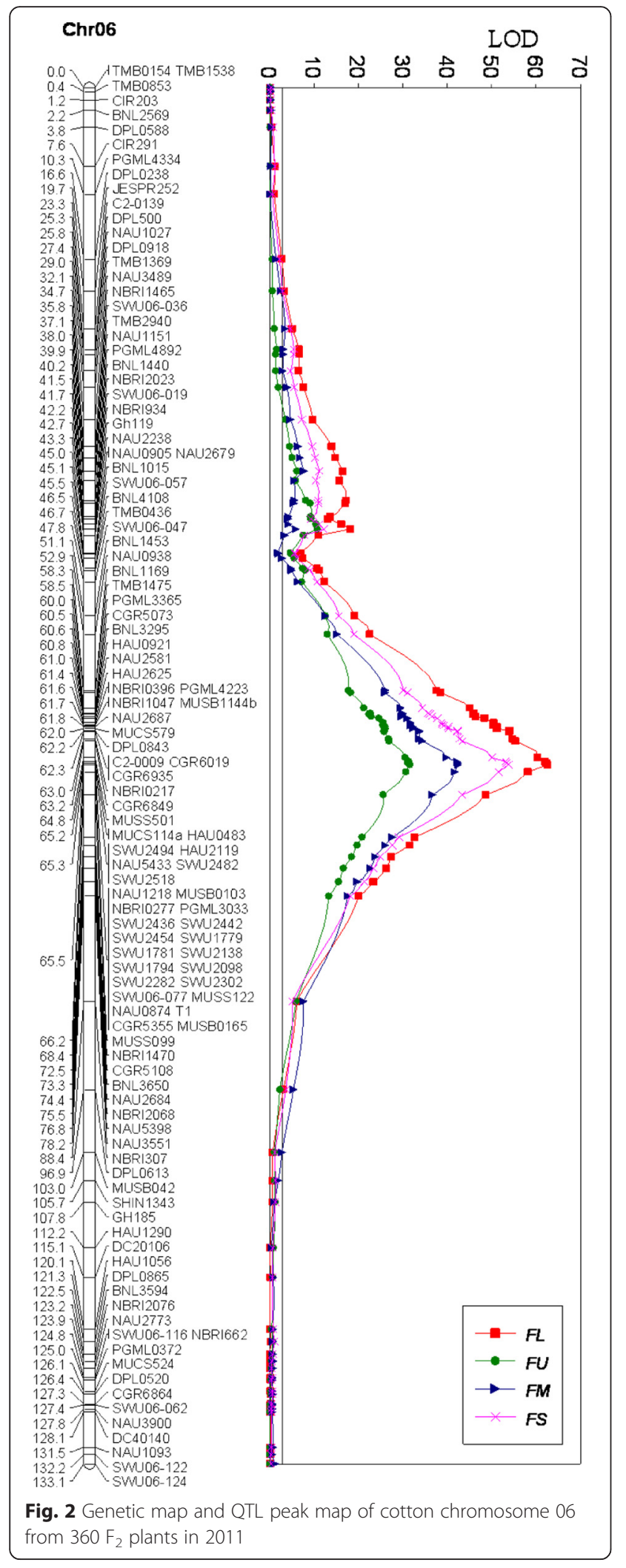

$\mathrm{T}_{1}$ ) mapped on chromosome 6 . The genetic map covered $133.1 \mathrm{cM}$ (Fig. 2). The QTL controlling four fiber quality traits was located in the confidence interval between MUCS114 and MUSS099, and 19 markers co-segregated with $\mathrm{T}_{1}$ (Fig. 2 and Table. 1). The QTL explained $59.3 \%$ $(\mathrm{LOD}=62.6), 45.7 \%(\mathrm{LOD}=42.6), 36.4 \%(\mathrm{LOD}=31.6)$ and $53.8 \%(\mathrm{LOD}=52.43)$ of phenotypic variation, with additive effects of $2.78,-0.43,1.90$ and 2.92 for FL, FM, FU and FS, respectively.

\section{High-resolution mapping}

To further define the QTL controlling fiber quality traits, all 26 markers in the confidence interval between MUCS114 and MUSB0165 were employed to genotype the 1434 $\mathrm{F}_{2}$ plants in 2011. The confidence interval for the position of the QTL from the peak LOD to less than 1, the QTL controlling fiber quality traits was mapped within a 0.35-cM interval between MUCS114 and SWU2302, and co-segregated with $\mathrm{T}_{1}$ and 17 SSR markers (Fig. 3 and Table 2). The QTL explained $54.7 \%(\mathrm{LOD}=222.3)$, $40.5 \%(\mathrm{LOD}=145.0), 30.1 \%(\mathrm{LOD}=100.4)$, and $50.0 \%$ $(\mathrm{LOD}=194.3)$ of total phenotypic variation, with additive effects of $2.65,-0.41,1.83$ and 2.91 for FL, FM, FU and FS, respectively.

To assess and facilitate genetic mapping, all SSR markers on the genetic map were used to do Blastn searches against G. raimondii and G. hirsutum genome sequences [10, 14]. All markers could be aligned to the reference genomes, as shown in Fig. 4c, 4d and Additional file 7 . The $0.28-\mathrm{cM}$ genetic interval corresponded to a $2.7-$ $\mathrm{Mb}$ physical distance on chromosome 10 in the $G$. raimondii genome and a 4.4-Mb physical distance on chromosome A06 in the G. hirsutum genome. Compared to the genome-wide averages of $0.33 \mathrm{Mb}$ per $\mathrm{cM}$ for $\mathrm{G}$. raimondii and $0.6 \mathrm{Mb}$ per cM for G. hirsutum [10, 46], this result suggested that recombination suppression occurred in the region where the QTL located.

\section{QTL substitution mapping}

For further dissection of the QTL controlling fiber quality traits, another 5535 plants were planted in 2012. The two SSR markers MUCS114 and SWU2302 were chosen to screen the recombinants in the QTL region from the 5535 plants. However, no recombination event was

Table 1 Biometrical parameters for QTL controlling fiber quality based on coarse mapping

\begin{tabular}{llrrc}
\hline Trait & LOD & \multicolumn{1}{l}{ A } & D & PV (\%) \\
\hline qFL & 62.6 & 2.78 & -0.10 & 59.3 \\
qFM & 42.6 & -0.43 & 0.27 & 45.7 \\
qFU & 31.6 & 1.90 & 0.28 & 36.4 \\
qFS & 52.4 & 2.92 & -0.33 & 53.8 \\
\hline
\end{tabular}

$A$ is additive effect of the Yumian 1 allele, $D$ is dominant effect of the Yumian 1 allele, $P V$ is percentage of total phenotypic variance explained by the QTL 


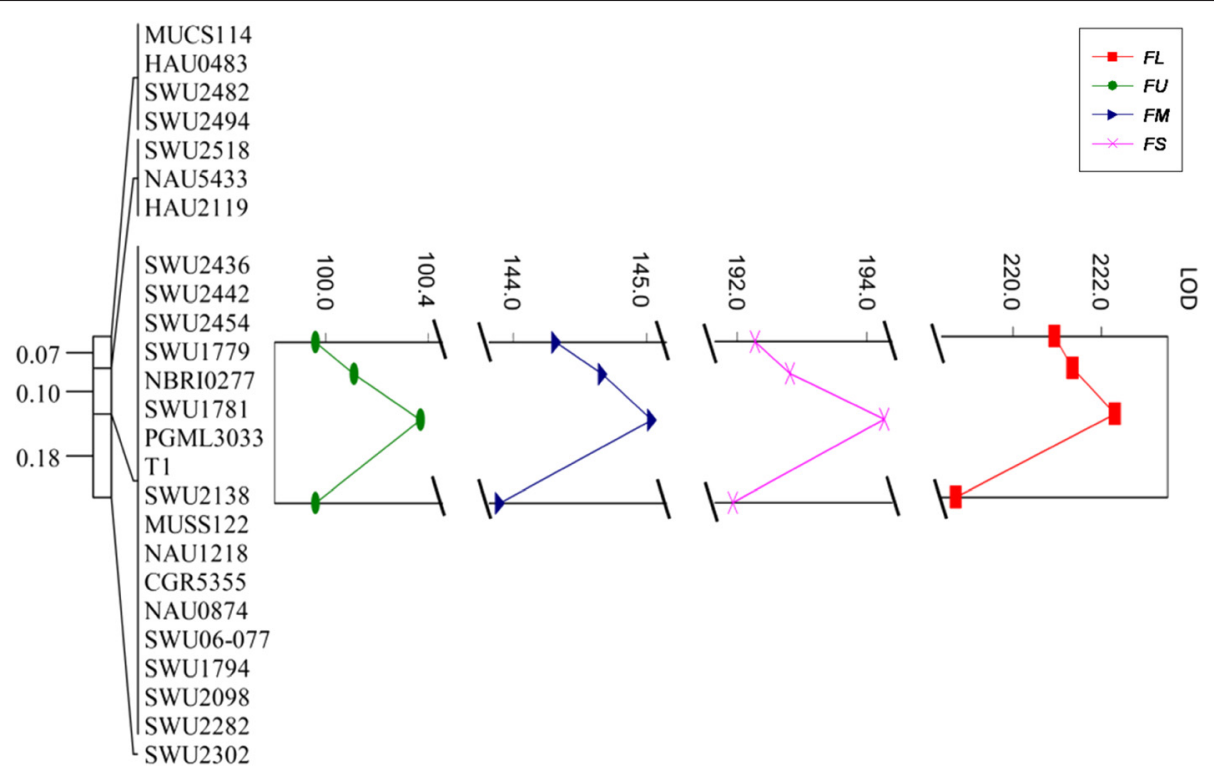

Fig. 3 Genetic map of the QTL region and trace of the log probabilities for the four fiber quality traits. The genetic map and QTL identification come from $1440 \mathrm{~F}_{2}$ plants in 2011. The genetic distances between adjacent markers are shown to the left of chromosomes

detected between $\mathrm{T}_{1}$ and the $16 \mathrm{SSR}$ markers, including SWU2436, SWU2442, SWU2454, SWU1779, NBRI0277, SWU1781, PGML3033 SWU2138, MUSS122, NAU1218, CGR5355, NAU0874, SWU06-77, SWU1794, SWU2098 and SWU2282 (Fig. 3). A total of 51 recombinants representing different recombination events between MUCS114 and SWU2302 in the 6975 plants were grouped into 14 classes, and the genotypes of recombinant classes are shown in Fig. 4d. The recombinant groups in the first category included recombinant classes 2, 3, 6 and 14, which placed the QTL downstream of SWU2494. The recombinant groups in the second category included recombinant classes 1, 5, 9, 12 and 13,which placed the QTL downstream of HAU2119. The recombinant groups in the third category included recombinant classes 4, 7, 8,10 and 11, which placed the QTL up stream of SWU2302. Therefore, the QTL controlling fiber quality traits was mapped into a 0.28-cM interval between HAU2119 and SWU2302.

\section{Comparison of fiber development}

To examine fiber cell differentiation in Yumian 1 and RIL118, scanning electron microscopy was used to

Table 2 Biometrical parameters for QTL controlling fiber quality based on fine mapping

\begin{tabular}{llrc}
\hline Trait & LOD & A & PV (\%) \\
\hline qFL & 222.3 & 2.65 & 54.7 \\
qFM & 145.0 & -0.41 & 40.5 \\
qFU & 100.4 & 1.83 & 30.1 \\
qFS & 194.3 & 2.91 & 50.0 \\
\hline
\end{tabular}

$A$ is additive effect of the Yumian 1 allele, $P V$ is percentage of total phenotypic variance explained by the QTL observe the development of fiber cell initials in the ovular surface at $1 \mathrm{DPA}$, and anatomy microscopy was used to observe progress in fiber cell elongation at 3 DPA, 5 DPA and 7 DPA. The fiber length of Yumian 1 was much longer than that of RIL118 from 3 to 7 DPA (Fig. 5). This result showed that fiber development at an early stage has a positive effect on final fiber quality.

\section{Identification of QTL candidate genes}

To better understand the molecular basis of early fiber development, RNA extracted from 0 DPA ovules and 5 DPA fibers was sequenced using an Illumina Hiseq 2500 platform. An overview of the sequencing and assembly was outlined in Table 3. With the removal of low quality tags, a total of 10 million and 14 million high-quality clean reads were obtained from 0 DPA ovules and 5 DPA fibers mRNA libraries, respectively. Ninety-four percent of the clean reads had Phred-like quality scores at the Q30 level (an error probability of 0.01 ). Approximately $80 \%-83 \%$ of the distinct tags (83-87 \% of the total tags) could be mapped uniquely to the $G$. raimondii reference sequence [10], while small proportions (3.5-3.9\%) were mapped to multiple loci in the reference genome (Additional file 8).

The total number of mapped reads for all identified transcripts was used for differential expression analysis in DESeq with $\mid \log 2$ (Fold Change) $\mid>1$ and $q$ value $<0.005$. There were 1262 genes with significantly different expression levels between Yumian 1 and RIL118 at 0 DPA ovules, among which 1006 were up-regulated and 256 were down-regulated in Yumian 1 (Fig. 6a). There were 4436 genes with significantly different expression levels between Yumian 1 and RIL118 at 5 DPA fibers, among 


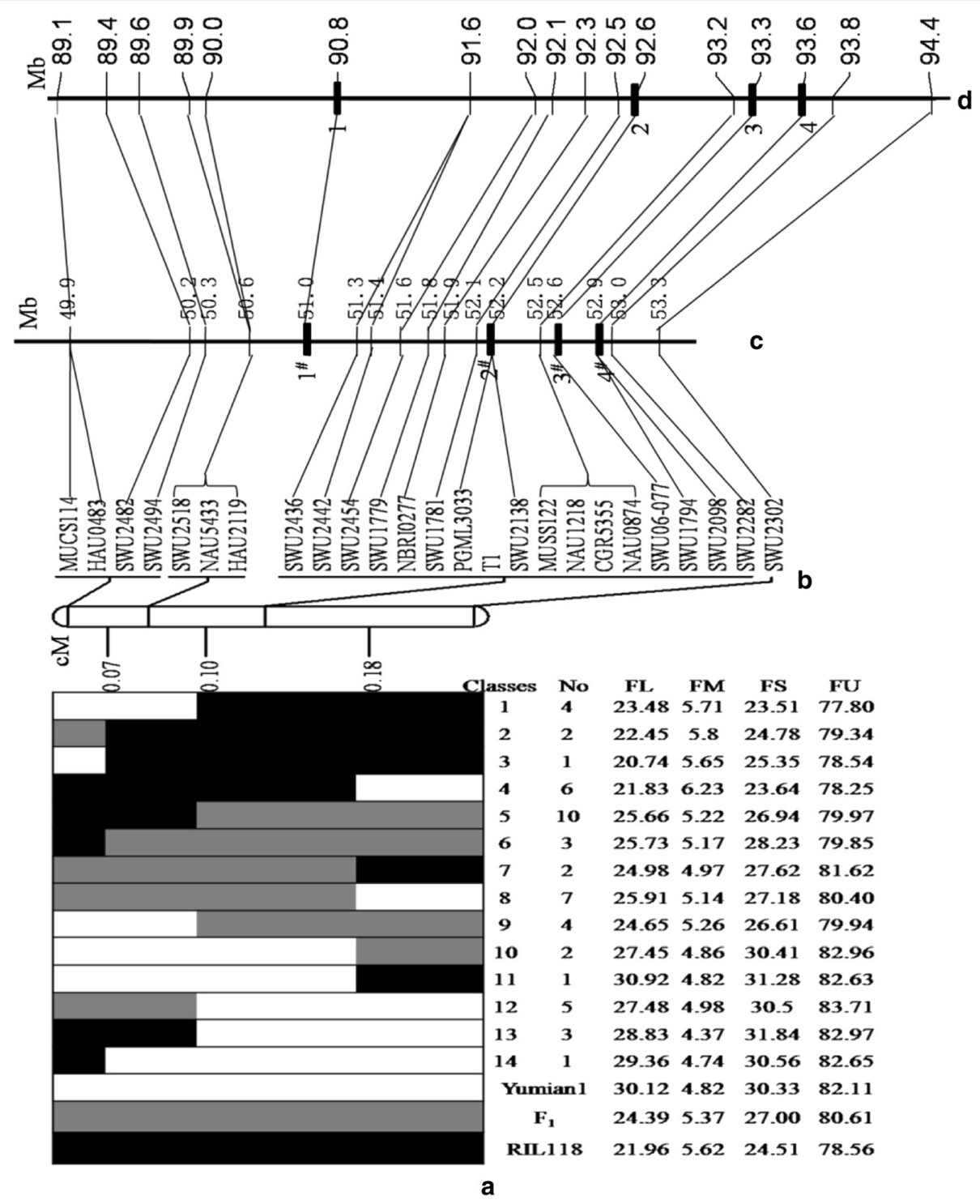

Fig. 4 a Graphical genotypes and fiber quality traits for recombinants derived from 6975 individuals. White, black and gray bars represent genotypes of Yumian 1, RIL118and heterozygotes, respectively. $\mathbf{b}$ The genetic map (CM) for the QTL region. $\mathbf{c}$ The physical locations (Mb) of markers and genes on chromosome 10 of the $\mathrm{G}$. raimondii genome sequence and on $\mathbf{d}$ chromosome A06 of the G. hirsutum TM-1 genome sequence. The physical distances of the chromosomes on the plots are represented by cells of different sizes according to the ratio of the chromosome lengths. The candidate genes suggested by RNA-Seq are highlighted with black squares. The figures in turn indicate genes from the G. hirsutum genome: GhA06G1256, GhA06G1277, GhA06G1301 and GhA06G1313. The figures with \# in turn indicate genes from the G. raimondii genome: Gorai.010G174800, Gorai.010G177300, Gorai.010G180100 and Gorai.010G181500. The same number of genes indicates the analogous gene of the reference genome

which 2315 were up-regulated and 2121 were downregulated in Yumian 1 (Fig. 6b). Combining the two timepoints of cotton fiber development, 457 significantly differentially expressed genes were observed with a consistent high-or-low variation between 0 DPA ovules and 5 DPA fibers (Fig. 6c). KEGG pathway-based analysis facilitated systematical study on complicated metabolic pathways and biological behaviors of functional molecules. Among differentially expressed genes comparing RIL118 and Yumian1, there were 107 and 122 pathways determined at the 0 DPA ovule and 5 DPA fiber, respectively. The most 20 pathways significantly enriched genes at two stages were showed in Additional file 9.

Among the transcripts aligned to the G. raimondii genome, four extremely differentially expressed genes were found within the QTL region between HAU2119 and SWU2302 on chromosome 10 (corresponding to chromosomes 6 and 25 of tetraploid cotton) (Fig. 4b). These genes are Gorai.010G174800, Gorai.010G177300, Gorai.010G180100 and Gorai.010G181500 in G. 


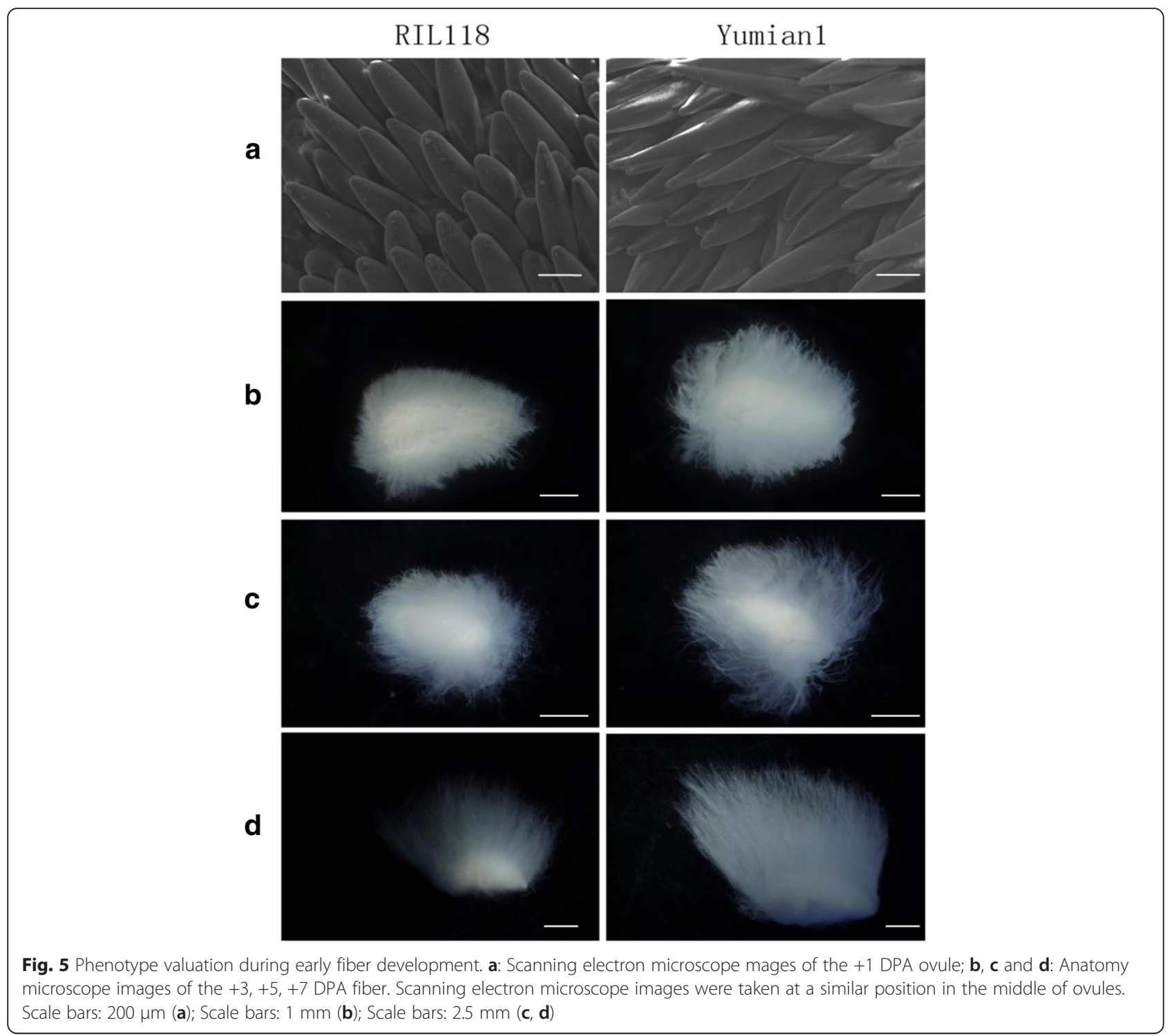

raimondii (Table 4c), which are putative homologues of GhA06G1256, GhA06G1277, GhA06G1301, GhA06 G1313 in the corresponding G. hirsutum region (Fig. 4d and Additional file 7).

To confirm whether the digital gene expression results were reliable, and to investigate the activation of four differentially expressed genes in the QTL region, we further tested the four genes using qRT-PCR in young leaf and fiber tissues across six time-points, designing primers from the A-subgenome of G.hirsutum [14]. The qRT-PCR analysis demonstrated that three of the four genes were expressed in a manner consistent with the RNA-Seq results (Fig. 7). Among them, GhA06G1256, homologous to Gorai.010G174 800 , exhibited a dramatic increase in 5 DPA fiber of RIL118.

Table 3 Summary of sequence assembly after Illumina sequencing

\begin{tabular}{lllccccc}
\hline Sample name & Raw reads & Clean reads & Clean bases & Error rate (\%) & Q20 (\%) & Q30 (\%) & GC content (\%) \\
\hline R118_0 & 10144830 & 9985483 & $0.5 G$ & 0.01 & 97.94 & 94.16 & 43.74 \\
Yumian 1_0 & 11213370 & 11081107 & $0.55 G$ & 0.01 & 98.01 & 94.35 & 43.77 \\
R118_5 & 14141978 & 14104947 & $0.71 G$ & 0.01 & 99.03 & 96.58 & 44.01 \\
Yumian 1_5 & 14027353 & 13969205 & $0.7 G$ & 0.01 & 98.99 & 96.49 & 43.94 \\
\hline
\end{tabular}

Raw reads: Statistical data for the original sequences. Clean reads: Calculation method is the same as for raw reads, but the statistics file is the filtered data. Clean bases:sequence number*sequence length (transformed into G bases). Q20、Q30:Percentage of the number of bases of Phred score greater than 20, 30 respectively. GC content:Percentage of G and $C$ bases among the total base number 


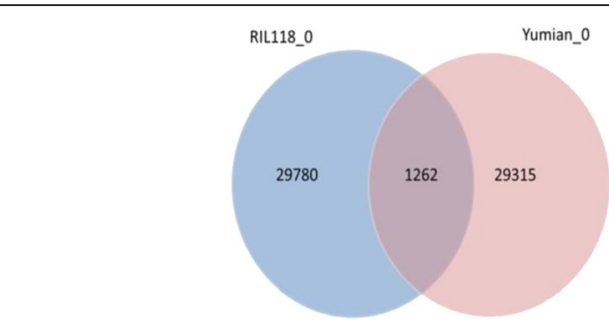

a

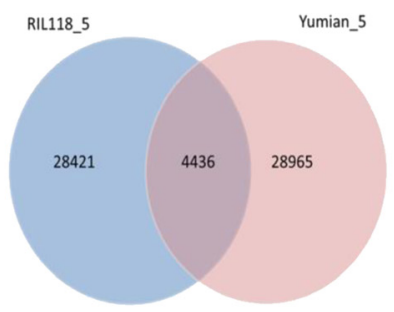

b

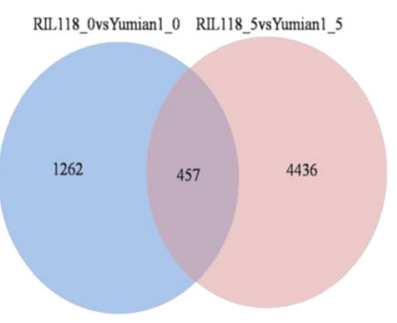

C

Fig. $\mathbf{6}$ Venn diagram showing the number of differentially expressed genes in ovules and fibers. a b Differentially expressed genes between RIL118 and Yuan 1 on 0 DPA ovule and 5DPA fiber; c The expression of regulated genes were significantly different between two joint time points ( $P$-value $<0.05$ and fold change $>1)$

GhA06G1277, homologous to Gorai.010G177300 was upregulated in Yumian 1. GhA06G1301, homologous to Gorai.010G180100, had higher transcript levels in Yumian 1 than inRIL118. However, the qRT-PCR result for GhA06G1 313, homologous to GhA06G1313 homologous to Gor ai.010G181500, was not entirely consistent with RNA-Seq. The RNA-Seq data for this gene at different fiber development points was not supported well by qRT-PCR analysis. RNA-Seq data analysis based on the G. raimondii genome may reflect expression of both $A$ and $D$ subgenome-derived loci in G. hirsutum, and qRT-PCR data may only reflect the expression of A subgenome genes of G. hirsutum.

\section{Discussion}

\section{Major QTL affecting fiber quality traits at $T_{1}$ locus}

$\mathrm{T}_{1}$ imparts heavy pubescence on the vegetative parts of cotton and is associated with short, coarse fibers [38].
Several workers $[47,48]$ have backcrossed $t_{1} t_{1}$ into $T_{1} T_{1}$ lines, and none have broken the short and coarse fiber in $\mathrm{T}_{1} \mathrm{~T}_{1}$ plants without selection. In order to further understand the relationship between $\mathrm{T}_{1}$ and fiber traits, Kloth found that the $\mathrm{T}_{1}$ marker accounted for $10-75 \%$ of the phenotypic variation associated with seven fiber traits, and suggested that the $\mathrm{T}_{1}$ locus is linked to (or pleiotropic with) numerous loci that influence fiber traits.

Based on a RFLP map of QTLs affecting density of leaf and stem trichomes, Wright et al. first mapped the $\mathrm{T}_{1}$ locus on chromosome 6, and Lacape et al. and Guo et al. [49] later reported pubescence to map to the same region. QTL for leaf and stem pubescence [50], and QTL for FL, FM, FE, and FU [51-53] have also been mapped to the $\mathrm{T}_{1}$ region on chromosome 6 in tetraploid cotton. Our previous studies mapped $\mathrm{T}_{1}$ and the QTL for fiberrelated traits between marker BNL3650 and BNL4108
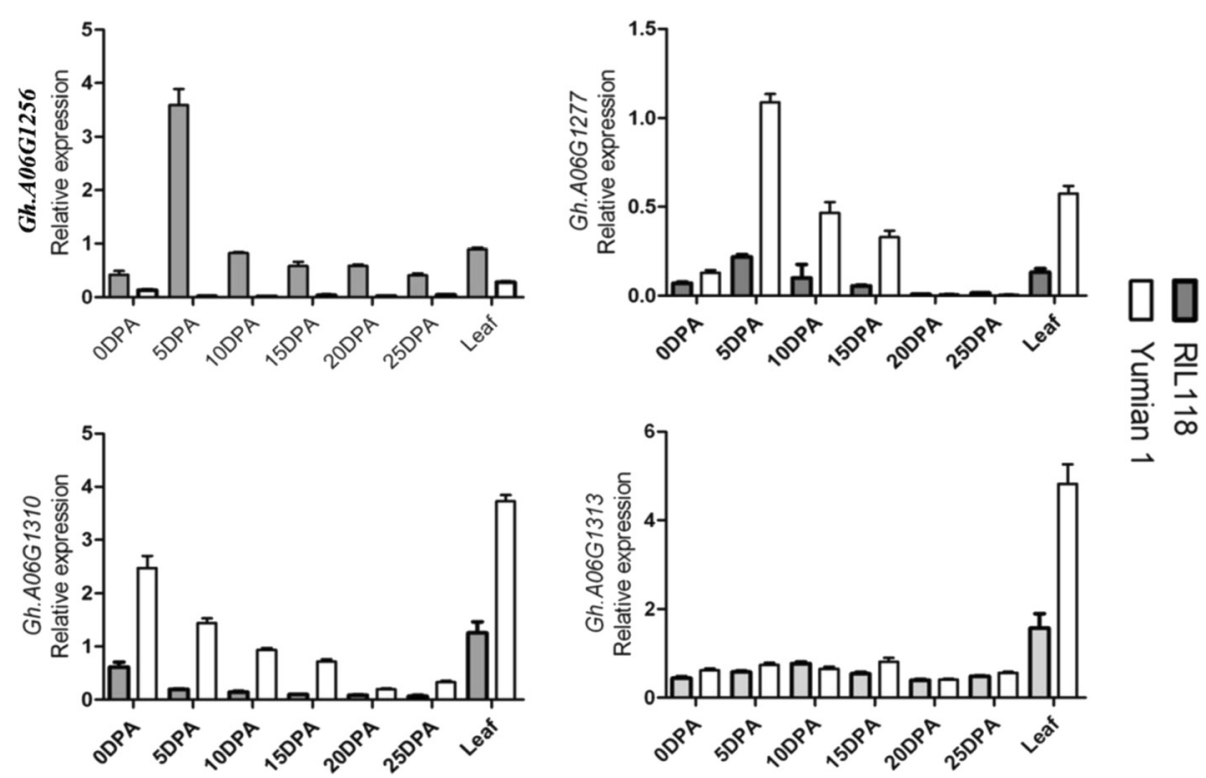

Fig. 7 RT-PCR expression of the differentially expressed genes in leaf and during fiber development of RIL118 and Yumian1. All data were normalized to the expression level of actin. Error bars indicate standard deviation of three biological replicates 
Table 4 Differentially expressed genes within the interval between SWU2302 and HAU2119

\begin{tabular}{lcccccccc}
\hline Gene ID & FPKM & & & & $\log _{2} F C \_0$ & & $\log _{2} F C \_5$ & Gene annotation \\
\cline { 2 - 5 } & R118_0 & Yumian1_0 & R118_5 & Yumian1_5 & & & & \\
\hline Gorai.010G174800 & 298.9 & 110.3 & 2083.4 & 74.0 & 1.4 & 4.8 & AL7B4 \\
Gorai.010G177300 & 1.49 & 19.9 & 4.1 & 24.5 & -3.8 & -2.6 & XTH_8 \\
Gorai.010G180100 & 68.6 & 152.4 & 69.0 & 138.2 & -1.2 & -1.0 & UGPI6 \\
Gorai.010G181500 & 42.1 & 106.80 & 49.6 & 106.2 & -1.3 & -1.1 & GCST \\
\hline
\end{tabular}

FPKM fragments per kilo base of exon per million fragments mapped, FC fold changes

on chromosome $6[36,37,45]$. The present study mapped $\mathrm{T}_{1}$ and the QTL controlling fiber quality traits to a $0.28-\mathrm{cM}$ interval. These results suggested that a major QTL affecting fiber quality traits exists at, or very near, the $\mathrm{T}_{1}$ locus.

\section{Recombination suppression}

In the present study, $\mathrm{T}_{1}$ and the QTL controlling fiber qualities were mapped into a $0.28-\mathrm{cM}$ interval between HAU2119 and SWU2302 on chromosome 6 from a $F_{2}$ population with 6975 individuals. The 0.28-cM interval corresponded to a $2.7-\mathrm{Mb}$ physical distance on chromosome 10 in the G. raimondii genome [10], and a $5.3-\mathrm{Mb}$ physical distance on chromosome A06 in the G. hirsutum genome [14]. The average ratio of physical-to-genetic distance is about $600 \mathrm{~kb} / \mathrm{cM}$ in tetraploid cotton [46]. This result indicated that substantial recombination suppression occurred in the region where the QTL was located. The recombination suppression might come from the origin and position of the $T_{1}$ region. $T_{1}$ region might come from Hawaiian wild tetraploid cotton (G. tomentosum) [54, 55], and also might be adjacent to the centromere. The centrome reregion is often associated with depression of meiotic recombination [56]. Recombination suppression was also found on chromosome 24 with a major QTL controlling fiber qualities from the population with line 7235 as one mapping parent, whose chromosome 24 might come from G. barbadense or G. anomalum [57-59]. The suppressed recombination in these regions suggests that positional cloning of the QTL causal gene may be very challenging.

\section{Identification of candidate genes for QTL controlling fiber quality traits}

Our study showed that fiber length of Yumian1 was much longer than that of RIL118 at early development stages (from 1 to 7 DPA). RNA-Seq and qRT-PCR analysis showed that only three genes GhA06G1256, GhA06G1277 and GhA06G1301 in the QTL region were differentially expressed in the fiber of Yumian 1 and RIL118. GhA06G1256 encodes a superfamily of aldehydedehydrogenases (ALDH), which can oxidize many endogenous aromatic and aliphatic aldehydes, creating carboxylic acids [60]. Family 7 aldehydedehydrogenase genes were essential for responsiveness to osmotic stress in leaves and seeds. Fiber development seemed to be concerned with changes in cell turgor pressure [61] and achieved expansion through the influx of water driven by a relatively high concentration of osmoticum within a cell [62]. Our result was consistent with the report that the expression of GhA06G1256 decreased gradually in the fiber of wild type cotton but is just the opposite in a fuzzless mutant during early development [63]. GhA06G1277 codes a xyloglucan endotransglycosylase/hydrolase (XTH), an enzyme that catalyzes the cleavage of donor xyloglucan chains and the reconnection of their reducing ends to non-reducing ends of other xyloglucan molecules. Some XTH genes have been reported to loosen cell walls and lead cell expansion and elongation [64]. The relationship of XTH activity and cell elongation has been reported in elongating fiber [65, 66]. It was also observed that XTH activity of wild-type fiber was higher than that of the $\mathrm{Li}_{1}$ mutant and the xyloglucan content was lower in wild-type [67]. OsXTH8 was highly expressed in vascular bundles of leaf sheath and young nodal roots where the cells are actively undergoing elongation and differentiation [68]. GhA06G1301 encodes a plant-specific glycosylphosphatidylinositol (GPI)-anchored protein, and have been found to play roles in primary cell walls and secondary cell walls cellulose biosynthesis. GPI-anchored proteins have various impacts on plant growth including root hair development $[69,70]$, plant height $[71]$, and pollen development [72]. In further studies, we will clone these candidate genes from the genome and cDNA and investigate the relationship between candidate genes and fiber quality traits through transgenic technology.

\section{Genetic dissection of complex traits through fine mapping and RNA-Seq}

The elucidation of gene and phenotype relationships remains a major challenge in biology. Fine mapping of interesting traits is an important basis for gene or QTL cloning, but experimental approaches are labor-intensive, time-consuming and expensive [73]. In order to reduce the number of candidate genes, here it was possible to form a bridge between the approaches of QTL mapping and transcriptomics [34]. Gilbert et al. [74] and Thyssen et al. [75] mapped candidate genes for the mutants $\mathrm{Li}_{1}$ 
and $\mathrm{Li}_{2}$ by the use of genomic and genetic data. In the present study, a QTL controlling fiber quality traits was mapped using a large population (6975 plants), to a 0.28$\mathrm{cM}$ interval corresponding to a $2.7-\mathrm{Mb}$ physical distance on chromosome 10 in the G. raimondii genome [10] and a 5.3-Mb physical distance on chromosome A06 in the G. hirsutum genome [14]. Although many markers existed in the region, the resolution of QTL mapping could not be improved due to recombination suppression in the region. However, based on expression profiling, four candidate genes were mapped to the QTL region. These studies showed that the combination of fine mapping and RNASeq is a powerful strategy to identify candidate genes for QTL controlling complex traits. RNA-seq technology has superior advantages on comparison with gene expression arrays, however, it contains significant blind spots on the gene structure alterations with the same expression level. For the next work, we will clone all the genes and confirm which one is the major QTL controlling fiber quality.

\section{Fiber quality determined during early fiber development}

Through comparing different cotton genotypes or species, insights are emerging about the time in development at which cotton fiber quality is established. Seagull et al. [76] reported that the fibers of G. barbadense started out much finer than those of G. hirsutum and fiber fineness was mainly determined by their initial diameter. Global gene expression profiling between G. hirsutum and G. barbadense showed that few meaningful differences were found at the fiber thickening stage, whereas the most significant differences were found at earlier stages of development, which suggested that their different final fiber quality properties may be established at earlier stages of fiber development [77]. Another study showed that targeted expression of the IAA biosynthetic gene iaaM in the epidermis of cotton ovules at the fiber initiation stage had increased fiber fineness [78]. Our study showed that fiber length and genes ( $A L D H, X T H$ and GPI-anchored protein) related to fiber elongation were significantly different between long fiber cultivar Yumian 1 and short fiber line RIL118 at the early development stage. These results support the hypothesis that final fiber quality might be determined during early fiber development.

\section{Conclusion}

In summary, a major QTL controlling four fiber quality traits is finely mapped to a $0.28-\mathrm{cM}$ interval at $\mathrm{T}_{1}$ region, which correspondes to a $2.7-\mathrm{Mb}$ physical distance on the chromosome 10 in G. raimondii genome and a $4.4-\mathrm{Mb}$ physical distance on chromosome A06 in G. hirsutum genome. This finding indicates that substantial recombination suppression occurring in the region where the QTL is located. Fiber length of Yumian 1 was much longer than that of RIL118 on 3 DPA and later. RNA-sequencing and RT-
PCR analysis showed that three genes are largely expressed between the two parents in the fiber development. These three genes may be candidate genes within the major QTL controlling fiber quality traits.

\section{Availability of supporting data}

The RNA-seq data discussed in this publication have been deposited in the Sequence Read Archive of NCBI under the accession number SRP070870. The data sets supporting the results of this article are included within the article and its additional files.

\section{Additional files}

Additional file 1: Table S1. RT-PCR primer developed from G. hirsutum genome sequence. (XLSX $10 \mathrm{~kb})$

Additional file 2: Figure S1. The frequency distribution of five fiber quality traits in 1434-individual $F_{2}$ population in 2011. (DOCX $607 \mathrm{~kb}$ )

Additional file 3: Table S2. Phenotypic variation of fiber quality traits in $1434 \mathrm{~F}_{2}$ population. (XLSX $11 \mathrm{~kb}$ )

Additional file 4: Table S3. Average value of fiber quality related traits for different trichome phenotype. (XLSX $10 \mathrm{~kb}$ )

Additional file 5: Table S4. Correlation coefficient among fiber quality traits in $\mathrm{F}_{2}$ population. (XLSX $10 \mathrm{~kb}$ )

Additional file 6: Table S5. New SSR markers developed from G. raimondii genome sequence. (XLSX $11 \mathrm{~kb}$ )

Additional file 7: Table S6. The physical locations of markers and genes on the reference genomes. (XLSX $11 \mathrm{~kb}$ )

Additional file 8: Table S7. Overview of Mapping Status by RNA-Seq. (XLSX $11 \mathrm{~kb}$ )

Additional file 9: Figure S2. KEGG analysis results of differentially expressed genes at the 0 DPA ovule and 5 DPA fiber comparing RIL118 and Yumian1. (DOCX $195 \mathrm{~kb}$ )

\section{Abbreviations}

DPA: days post-anthesis; FE: fiber elongation; FL: fiber length; FM: fiber micronaire reading; FPKM: fragments per kilo base of exon per million fragments mapped; FS: fiber strength; FU: uniformity ratio; KEGG: Kyoto encyclopedia of genes and genomes; LOD: log of odds ratio; MAS: markerassisted selection; QTL: quantitative trait loci; RIL: recombinant inbred line; RNA-seq: high-throughput sequencing of RNA; RT-PCR: real-time quantitative PCR.

\section{Competing interests}

The authors declare that they have no competing interests.

\section{Authors' contribution}

LDX and ZJ contributed to DNA and RNA extraction, genotyping, data analysis and writing; $L X Y$ and $W W W$ contributed to SSR development and data analysis; FXM, TSY, TZY, YJH and ZJW contributed to DNA extraction and genotyping; TZH and LDJ contributed to population construction; ZZS contributed to experimental design and writing. All authors read and approved the final manuscript.

\section{Acknowledgements}

This study was financially supported by the Natural Science Foundation of China (31270037, 30900910), Fundamental Research Funds for the Central Universities(XDJK2016C155, XDJK2014A003), Research Fund for the Doctoral Program of Higher Education of China (20120182110006), Hi-tech Research and Development Program of China (2012AA101108) and the 111 Project (B12006).

Received: 23 October 2015 Accepted: 28 March 2016 Published online: 19 April 2016 


\section{References}

1. O'Brien RD, Jones LA, King CC, Wakelyn PJ, Wan PJ. Cottonseed oil. In: Shahidi F, editor. Bailey's industrial oil and fat products. 6th ed. New Jersey: Wiley; 2005.

2. Kim HJ, Triplett BA. Cotton fiber growth in planta and in vitro: models for plant cell elongation and cell wall biogenesis. Plant Physiol. 2001;127:1361-6.

3. Yang SS, Cheung F, Lee JJ, Ha M, Wei NE. Accumulation of genome-specific transcripts, transcription factors and phytohormonal regulators during early stages of fiber cell development in allotetraploid cotton. Plant J. 2006;47:761-75.

4. Lee JJ, Woodward AW, Chen ZJ. Gene expression changes and early events in cotton fibre development. Ann Bot. 2007;100:1391-401.

5. Walford S, Wu Y, Llewellyn D, Dennis E. Epidermal cell differentiation in cotton mediated by the homeodomain leucine zipper gene, GhHD-1. Plant J. 2012;71(3):464-78.

6. Said Jl, Song MZ, Wang HT, Lin ZH, Zhang XL, Fang DD, Zhang JF. A comparative meta-analysis of QTL between intraspecifc Gossypium hirsutum and interspecifc $G$. hirsutum × G. barbadense populations. Mol Genet Genomics. 2015;290(3):1003-25.

7. Chen H, Qian N, Guo W, Song Q, Li B, Deng F, Dong C, Zhang T. Using three overlapped RILs to dissect genetically clustered QTL for fiber strength on Chro.D8 in Upland cotton. Theor Appl Genet. 2009;119:605-12.

8. Shen X, He Y, Lubbers EL, Davis RF, Nichols RL, Chee PW. Fine mapping QMi-C11 a major QTL controlling root-knot nematodes resistance in Upland cotton. Theor Appl Genet. 2010;121:1623-31.

9. Su CF, Wang W, Qiu XM, Yang L, Li S. Fine-mapping a fibre strength QTLQFS-D11-1 on cotton chromosome 21 using introgressed lines. Plant Breed. 2013;132(6):725-30.

10. Paterson AH, Wendel JF, Gundlach H, Guo H, Jenkins J, Jin DC, Llewellyn D, Showmaker KC, Shu SQ, Udall J, Yoo MJ, Byers R, Chen W, Doron-Faigenboim A, Duke MV, Gong L, Grimwood J, Grover C, Grupp K, Hu GJ, Lee TH, Li JP, Lin LF, Liu T, Marler BS, Page JT, Roberts AW, Romanel E, Sanders WS, Szadkowski E, Tan X, Tang HB, Xu CM, Wang JP, Wang ZN, Zhang D, Zhang L, Ashrafi H, Bedon F, Bowers JE, Brubaker CL, Chee PW, Das S, Gingle AR, Haigler CH, Harker D, Hoffmann LV, Hovav R, Jones DC, Lemke C, Mansoor S, Rahman MU, Rainville LN, Rambani A, Reddy UK, Rong JK, Saranga Y, Scheffler BE, Scheffler JA, Stelly DM, Triplett BA, Van Deynze A, Vaslin MFS, Waghmare VN, Walford SA, Wright RJ, Zaki EA, Zhang TZ, Dennis ES, Mayer KFX, Peterson DG, Rokhsar DS, Wang XY, Schmutz J. Repeated polyploidization of Gossypium genomes and the evolution of spinnable cotton fibres. Nature. 2012:492:423-8.

11. Wang K, Wang Z, Li F, Ye W, Wang J, Song G, Yue Z, Cong L, Shang H, Zhu S, Zou C, Li Q, Yuan Y, Lu C, Wei H, Gou C, Zheng Z, Yin Y, Zhang X, Liu K, Wang B, Song C, Shi N, Kohel RJ, Percy RG, Yu JZ, Zhu Y-X, Wang J, Yu SX. The draft genome of a diploid cotton Gossypium raimondii. Nat Genet. 2012;44:1098-103.

12. Li FG, Fan GY, Wang KB, Sun FM, Yuan YL, Song GL, Li Q, Ma ZY, Lu CR, Zou CS, Chen WB, Liang XM, Shang HH, Liu WQ, Shi CC, Xiao GH, Gou CY, Ye WW, Xu X, Zhang XY, Wei HL, Li ZF, Zhang GY, Wang JY, Liu K, Kohel RJ, Percy RG , Yu J Z, Zhu YX, Wang J, Yu SX. Genome sequence of the cultivated cotton Gossypium arboretum. Nat Genet. 2014:46:567-72.

13. Li FG, Fan GY, Wang KB, Lu CR, Xiao GH, Zou CS, Kohe RJ, Ma ZY, Shang HH, Ma XF, Wu JY, Liang XM, Huang G, Percy RG, Liu K, Yang WH, Chen WB, Du XM, Shi CC, Yuan YL, Ye WW, Liu X, Zhang XY, Liu WQ, Wei HG, Wei SJ, Huang GD, Zhang XL, Zhu SJ, Zhang H, Sun FM, Wang XF, Liang J, Wang JH, He Q, Huang LH, Wang J, Cui JJ, Song GL, Wang KB, Xu X, Yu JZ, Zhu YX, Yu SX. Genome sequence of cultivated Upland cotton (Gossypium hirsutum TM-1) provides insights into genome evolution. Nat Biotech. 2015;33:524-30.

14. Zhang TZ, Hu Y, Jiang WK, Fang L, Guan XY, Chen JD, Zhang JB, Saski CA, Scheffler BE, Stelly DM, Hulse-Kemp AM, Wan Q, Liu BL, Liu CX, Wang S, Pan MQ, Wang YK, Wang DW, Ye WX, Chang LJ, Zhang WP, Song QX, Kirkbride RC, Chen XY, Dennis E, Llewellyn DJ, Peterson DG, Thaxton P, Jones DC, Wang Q, Xu XY, Zhang H, Wu HT, Zhou L, Mei GF, Chen SQ, Tian Y, Xiang D, Li XH, Ding J, Zuo QY, Tao LN, Liu YC, Li J, Lin Y, Hui YY, CaoZS, Cai CP, Zhu XF, Jiang Z, Zhou BL, Guo WZ, Li RQ, Chen ZJ. Sequencing of allotetraploid cotton (Gossypiumhirsutum L. acc. TM-1) provides a resource for fiber improvement. Nat Biotech. 2015;33:531-7.

15. Wu Y, Machado AC, White RG, Llewellyn DJ, Dennis ES. Expression profiling identifies genes expressed early during lint fibre initiation in cotton. Plant Cell Physiol. 2006:47:107-27.

16. Taliercio EW, Boykin D. Analysis of gene expression in cotton fiber initials. BMC Plant Biol. 2007;17:22.

17. Alabady M, Eunseog Y, Wilkins T. Double feature selection and cluster analyses in mining of microarray data from cotton. BMC Genomics. 2008;9:295.

18. Hinchliffe DJ, Turley RB, Naoumkina M, Kim HJ, Tang Y, Yeater KM, Li P, Fang DD. A combined functional and structural genomics approach identified an EST-SSR marker with complete linkage to the Ligon lintless-2 genetic locus in cotton (Gossypium hirsutum L.). BMC Genomics. 2011;12:445.

19. Liu K, Sun J, Yao L, Yuan Y. Transcriptome analysis reveals critical genes and key pathways for early cotton fiber elongation in Ligonlintless-1 mutant. Genomics. 2012;100(1):42-50.

20. Machado A, Wu YR, Yang YM, Llewellyn DJ, Dennis ES. The MYB transcription factor GhMYB25 regulates early fibre and trichome development. Plant J. 2009:59:52-62

21. Walford S-A, Wu Y, Llewellyn DJ, Dennis ES. GhMYB25-like: a key factor in early cotton fibre development. Plant J. 2011;65:785-97.

22. Jiang YJ, Guo WZ, Zhu HY, Ruan YL, Zhang TZ. Over expression of GhSusA1 increases plant biomass and improves cotton fiber yield and quality. Plant Biotech J. 2012;10:301-12.

23. Deng F, Tu L, Tan J, Li Y, Nie Y, Zhang X. GbPDF1 is involved in cotton fiber initiation via the core cis-element HDZIP2ATATHB2. Plant Physiol. 2012;158:890-904

24. Huang GQ, Gong SY, Xu WL, Li W, Li P, Zhang CJ, Li DD, Zheng Y, Li FG, Li XB. A fasciclin-like arabinogalactan protein, GhFLA1, is involved in fiber initiation and elongation of cotton. Plant Physiol. 2013;161:1278-90.

25. Wang L, Cook A, Patrick JW, Chen XY, Ruan YL. Silencing the vacuolar invertase gene GhVIN1 blocks cotton fiber initiation from the ovule epidermis, probably by suppressing a cohort of regulatory genes via sugar signaling. Plant J. 2014;78:686-96.

26. Ruan YL, Llewellyn DJ, Furbank RT. Suppression of sucrose synthase gene expression represses cotton fiber cell initiation, elongation, and seed development. Plant Cell. 2003;15:952-64.

27. Li XB, Fan XP, Wang XL, Cai L, Yang WC. The cotton ACTIN1 gene is functionally expressed in fibers and participates in fiber elongation. Plant Cell. 2005;17:859-75.

28. Li D, Ruan X, Zhang J, Wu Y, Wang X, Li X. Cotton plasma membrane intrinsic protein 2s (PIP2s) selectively interact to regulate their water channel activities and are required for fibre development. New Phytol. 2013; 199:695-707.

29. Han LB, Li YB, Wang HY, Wu XM, Li CL, Luo M, Wu SJ, Kong ZS, Pei Y, Jiao GL, Xia GX. The dual functions of WLIMla in cell elongation and secondary wall formation in developing cotton fibers. Plant Cell. 2013;25:4421-38.

30. Shan CM, Shangguan XX, Zhao B, Zhang XF, Chao LM, Yang CQ, Wang LJ, Zhu HY, Zeng YD, Guo WZ, Zhou BL, Hu GJ, Guan XY, Chen ZJ, Wendel JF, Zhang TZ, Chen XY. Control of cotton fibre elongation by a homeodomain transcription factor GhHOX3. Nat Commun. 2014;5:5519.

31. Tang W, Tu L, Yang X, Tan J, Deng F, Hao J, Guo K, Lindsey K, Zhang X. The calcium sensor GhCaM7 promotes cotton fiber elongation by modulating reactive oxygen species (ROS) production. New Phytol. 2014;202:509-20.

32. Yang Z, Zhang C, Yang X, Liu K, Wu Z, Zhang X, Zheng Wu, Xun Q, Liu C, Lu L, Yang Z, Qian Y, Xu Z, Li C, Li J, Li F. PAG1, a cotton brassinosteroid catabolism gene, modulates fiber elongation. New Phytol. 2014;203:437-44.

33. Bolon YT, Joseph B, Cannon SB, Graham MA, Diers BW, Farmer AD, May GD, Muehlbauer GJ, Specht JE, Tu ZJ, Weeks N, Xu WW, Shoemaker RC, Vance CP. Complementary genetic and genomic approaches help characterize the linkage group I seed protein QTL in soybean. BMC Plant Biol. 2010;10:41.

34. Monclus R, Leplé JC, Bastien C, Bert PF, Villar M, Marron N, Brignolas F, Jorge $\checkmark$. Integrating genome annotation and QTL position to identify candidate genes for productivity, architecture and water-use efficiency in Populus spp. BMC Plant Biol. 2012;12:173.

35. Barrero JM, Cavanagh C, Verbyla KL, Tibbits JF, Verbyla AP, Huang BE, Rosewarne GM, Stephen S, Wang P, Whan A, Rigault P, Hayden MJ, Gubler F. Transcriptomic analysis of wheat near-isogenic lines identifies PM19-A1 and A2 as candidates for a major dormancy QTL. Genome Biol. 2015;16(1):93.

36. Wan Q, Zhang Z, Hu M, Chen L, Liu D, Chen X, Liu D, Chen X, Wang W, Zheng J. $T_{1}$ locus in cotton was the candidate gene affecting lint percentage, fiber quality and spiny bollworm (Earias spp.) resistance. Euphytica. 2007;158:241-7.

37. Zhang ZS, Hu MC, Zhang J, Liu DJ, Zhang K, Wang W, Wan Q. Construction of a comprehensive PCR-based marker linkage map and QTL mapping for fiber quality traits in (Gossypium hirsutum L.). Mol Breed. 2009;24:49-61.

38. Simpson D. Fuzzy leaf in cotton and its association with short lint. J Hered. 1947;38:153-6.

39. Kloth $\mathrm{RH}$. Quantitative trait loci affecting cotton fiber were linked to the $T_{1}$ locus in upland cotton. Theor Appl Genet. 1995;91:762-8.

40. Wright RJ, Thaxton PM, El-Zik KM, Paterson AH. Molecular mapping of genes affecting pubescence of cotton. J Hered. 1999;90:215-9. 
41. Lacape JM, Nguyen TB. Mapping quantitative trait loci associated with leaf and stem pubescence in cotton. J Hered. 2005;96(4):441-4.

42. Ding $M Q$, Ye WW, Lin LF, He S, Du XM, Chen AQ, Cao YF, Qin Y, Fen $Y$, Jiang YR, Zhang $H$, Wang XY, Paterson AH, Rong JK: The hairless stem phenotype of cotton ( $G$. barbadense) is linked to a copia-like retrotransposon insertion in homeodomainleucine zipper gene (HD1). Genet 2015, doi: 10.1534/genetics.115.178236

43. Liu DX, Liu F, Shan XR, Zhang J, Tang SY, Fang XM, Liu XY, Wang WW, Tan ZY, Teng ZH, Zhang ZS, Liu DJ. Construction of a high-density genetic map and lint percentage and cottonseed nutrient trait QTL identification in upland cotton (Gossypium hirsutum L.). Mol Genet Genomics. 2015;290(5):1683-700.

44. Luo M, Xiao Y, Li X, Lu X, Deng W, Li D, Hou L, Hu M, Li Y, Pei Y. GhDET2, a steroid $5 a$-reductase, plays an important role in cotton fiber cell initiation and elongation. Plant J. 2007;51(3):419-30.

45. Zhang ZS, Xiao YH, Luo M, Li XB, Luo XY, Hou L, Li DM, Pei Y. Construction of a genetic linkage map and QTL analysis of fiber-related traits in upland cotton (Gossypium hirsutum L.). Euphytica. 2005;144:91-9.

46. Rong J, Abbey C, Bowers JE, Brubaker CL, Chang C, Chee PW, Delmonte TA, Ding X, Garza JJ, Marler BS, Park CH, Pierce GJ, Rainey KM, Rastogi VK, Schulze SR, Trolinder NL, Wendel JF, Wilkins TA, Williams-Coplin TD, Wing RA, Wright RJ, Zhao X, Zhu L, Paterson AH. A 3347-locus genetic recombination map of sequence-tagged sites reveals features of genome organization, transmission and evolution of cotton (Gossypium). Genetics. 2004;166:389-41.

47. Kohel RJ, Lewis CF, Richmond TR. Isogenic lines in American upland cotton, Gossypium hirsutum L. preliminary evaluation of lint measurements. Crop Sci. 1967;7:67-70.

48. Lee JA. Effects of two pilosity alleles on agronomic and fibre traits in upland cotton. Crop Sci. 1984;24:127-9.

49. Guo WZ, Ma GJ, Zhu YC, Yi CX, Zhang TZ. Molecular tagging and mapping of quantitative trait loci for lint percentage and morphological marker genes in upland cotton. Integrat Plant Biol. 2006;48:320-6.

50. Desai A, Chee PW, May OL, Paterson AH. Correspondence of trichomes mutations in diploid and tetraploid Cottons. J Hered. 2008;99(2):182-6.

51. Chee $P$, Draye $X$, Jiang CX, Decanini L, Delmonte TA, Bredhauer $R$, Smith CW, Paterson AH. Molecular dissection of interspecific variation between Gossypium hirsutum and Gossypium barbadense (cotton) by a backcross-self approach: I. Fiber Elongation Theor Appl Genet. 2005;111:757-63.

52. Chee P, Draye X, Jiang CX, Decanini L, Delmonte TA, Bredhauer R, Smith CW, Paterson AH. Molecular dissection of interspecific variation between Gossypium hirsutum and Gossypium barbadense (cotton) by a backcross-self approach: III. Fiber Length Theor Appl Genet. 2005;111:772-81.

53. Draye $X$, Chee $P$, Jiang $C X$, Decanini $L$, Delmonte TA, Bredhauer $R$, Smith, CW, Paterson AH. Molecular dissection of interspecific variation between Gossypium hirsutum and Gossypium barbadense (cotton) by a backcross-self approach: II. Fiber fineness. Theor Appl Genet. 2005;111:764-11.

54. Knight RL, Sadd J. The genetics of jassid resistance in cotton.ll. The KapasPurao, Kawanda and Philippines Ferguson group. J Genet. 1954;52:186-98.

55. Knight RL. The genetics of jassid resistance in cotton. IV. Trsnsference of hairiness from Gossypium herbaceum to G. barbadense. J Genet. 1955;53:150-5.

56. Haupt W, Fischer TC, Winderl S, Fransz P, Torres-Ruize RA. The centromere1 (CEN1) region of Arabidopsis thaliana: architecture and functional impact of chromatin. Plant J. 2001;27:285-96.

57. Shen XL, Guo WZ, Lu QX, Zhu XF, Yuan YL, Zhang TZ. Genetic mapping of quantitative trait loci for fiber quality and yield trait by RIL approach in Upland cotton. Euphytica. 2007;155:371-80.

58. Kumar P, Singh R, Lubbers EL, Shen XL, Paterson AH, Campbell BT, Jones DC, Chee PW. Mapping and Validation of Fiber Strength Quantitative Trait Loci on Chromosome 24 in Upland Cotton. Crop Sci. 2012;52:1115-22.

59. Tang S, Teng Z, Zhai T, Fang X, Liu F, Liu D, Zhang J, Liu D, Wang S, Zhang K, Shao Q, Tan Z, Paterson AH, Zhang Z. Construction of genetic map and QTL analysis of fiber quality traits for Upland cotton (Gossypium hirsutum L.). Euphytica. 2015;201:195-213.

60. Kirch HH, Bartels D, Wei Y, Schnable PS, Wood AJ. The ALDH gene superfamily of Arabidopsis. Trends Plant Sci. 2004;9:371-7.

61. Ruan L, Llewellyn D, Furbank R. Pathway and control of sucrose import into initiating cotton fibers. Aust J Plant Physiol. 2000;27:795-800.

62. Cosgrove DJ. Assembly and enlargement of the primary cell wall in plants. Annu Rev Cell Dev Biol. 1997;13:171-201.
63. Wan Q, Zhang H, Ye WX, Wu HT, Zhang TZ. Genome-wide transcriptome profiling revealed cotton fuzz fiber development having a similar molecular model as Arabidopsis trichome. PLoS One. 2014;9(5):e97313.

64. Nwashitani K, Vwassenberg K. Roles of the XTH Family in the Expanding Cell. Berlin: Springer; 2007.

65. Michailidwas G, Argiriou A, Darzentas N, Tsaftaris A. Analysis of xyloglucanendotransglycosylase/hydrolase (XTH) genes from allotetraploid (Gossypium hirsutum) cotton and its diploid progenitors expressed during fiber elongation. J Plant Physiol. 2009;166(4):403-16.

66. Lee J, Burns TH, Light G, Sun Y, Fokar M, Kasukabe Y, Fujwasawa K, Maekawa Y, Allen RD. Xyloglucanendotransglycosylase/hydrolase genes in cotton and their role in fiber elongation. Planta. 2010;232:1191-205.

67. Shao MY, Wang XD, Ni M, Bibi N, Yuan SN, Malik W, Zhang HP, Liu YX, Hua SJ. Regulation of cotton fiber elongation by xyloglucan endotransglycosylase/ hydrolase genes. Genet Mol Res. 2011;10(4):3771-82.

68. Jan A, Yang G, Nakamura H, Ichikawa H, Kitano H, Matsuoka M, Matsuoka M. Characterization of a xyloglucan endotransglucosylase gene that is upregulated by gibberellin in rice. Plant Physiol. 2004;136(3):3670-81.

69. Jones MA, Raymond MJ, Smirnoff N. Analysis of the root-hair morphogenesis transcriptome reveals the molecular identity of six genes with roles in root-hair development in Arabidopsis. Plant J. 2006;45:83-100.

70. Hochholdinger F, Wen TJ, Zimmermann R, Chimot-Marolle P, Da Costa E, Silva O, Bruce W, Lamkey KR, Wienand U, Schnable PS. The maize (Zea mays L.) roothairless 3 gene encodes a putative GPI-anchored, monocot-specific, COBRAlike protein that significantly affects grain yield. Plant J. 2008;54:888-98.

71. Dai X, You C, Chen G, Li X, Zhang Q, Wu C. OsBC1L4 encodes a COBRA-like protein that affects cellulose synthesis in rice. Plant Mol Biol. 2011;75:333-45.

72. Dai X, You C, Wang L, Chen G, Zhang Q, Wu C. Molecular characterization, expression pattern, and function analysis of the OsBC1L family in rice. Plant Mol Biol. 2009;71:469-81.

73. Bai X, Wu B, Xing Y. Yield-related QTLs and their applications in rice genetic improvement. J Integr Plant Biol. 2012;54(5):300-11.

74. Gilbert MK, Turley RB, Kim HJ, Li P, Thyssen G, Tang Y, Delhom CD, Naoumkina M, Fang DD. Transcript profiling by microarray and marker analysis of the short cotton (Gossypium hirsutum L.) fiber mutant Ligon lintless-1 (Li1). BMC Genomics. 2013;14:403

75. Thyssen GN, Fang DD, Turley RB, Florane C, Li P, Naoumkina M. Next generation genetic mapping of the Ligon-lintless-2 $\left(\mathrm{Li}_{2}\right)$ locus in upland cotton (Gossypiumhirsutum L.). Theor Appl Genet. 2014;127:2183-92.

76. Seagull R, Oliveri V, Murphy K, Binder A, Kothar S. Cotton fiber growth and development 2. Changes in cell diameter and wall birefringence. J Cotton Sci. 2000:4:97-104.

77. Al-Ghazi Y, Bourot S, Arioli T, Dennis ES, Llewellyn DJ. Transcript profiling during fiber development identifies pathways in secondary metabolism and cell wall structure that may contribute to cotton fiber quality. Plant Cell Physiol. 2009;50(7):1364-81.

78. Zhang M, Zheng X, Song S, Zeng Q, Hou L, Li D, Zhao J, Wei Y, Li X, Luo M, Xiao Y, Luo X, Zhang J, Xiang C, Pei Y. Spatiotemporal manipulation of auxin biosynthesis in cotton ovule epidermal cell. Nat Biotech. 2011;29:453-8.

\section{Submit your next manuscript to BioMed Central and we will help you at every step:}

- We accept pre-submission inquiries

- Our selector tool helps you to find the most relevant journal

- We provide round the clock customer support

- Convenient online submission

- Thorough peer review

- Inclusion in PubMed and all major indexing services

- Maximum visibility for your research

Submit your manuscript at www.biomedcentral.com/submit
C) Biomed Central 